\title{
STUDIES ON COPPER METABOLISM. XI. COPPER AND IRON METABOLISM IN THE NEYHROTIC SYNDROME ${ }^{1}$
}

\author{
By G. E. CARTWRIGHT, C. J. GUBLER, AND M. M. WINTROBE \\ (From the Department of Medicine, University of Utah, College of Medicine, Salt Lake City, \\ Utah)
}

(Submitted for publication December 1, 1953; accepted January 20, 1954)

The metabolism of copper and iron in the nephrotic syndrome has received little attention. In view of the fact that copper in the plasma is bound almost exclusively to an $\alpha_{2}$-globulin (ceruloplasmin) with a molecular weight of approximately $151,000(1,2)$ while iron is bound to a $\beta_{1}$-globulin (transferrin) with a molecular weight of about 90,000 (3), it would seem not unlikely that these two metal-binding proteins might be excreted in large quantities in the urine of patients with pronounced proteinuria. If this loss were great and extended over a prolonged period, it is conceivable that depletion of the body stores of these two elements might occur or the capacity of the body to synthesize these two proteins might be exceeded, with the consequence that the plasma level of ceruloplasmin and transferrin would be reduced.

In the course of investigations in this laboratory concerning the anemia associated with infection (4), a patient was studied who, while afflicted with chronic osteomyelitis, developed the nephrotic syndrome. In association with the severe hypoproteinemia and proteinuria, the plasma copper level decréased from $246 \mu \mathrm{g}$. per $100 \mathrm{ml}$., the high levels usually found with infection, to $40 \mu \mathrm{g}$. per $100 \mathrm{ml}$. in spite of the continued presence of osteomyelitis. Móre recently (5) we observed hypocupremia in two of three children with the nephrotic syndrome. Munch-Petersen (6) has reported that the urinary excretion of copper is increased in patients with proteinuria and that the amount of copper excreted is greatest in those with the highest concentration of protein in the urine. Although he did not record the plasma copper values he stated that there was no correlation between the plasma copper concentration and the amount of copper in the urine.

1 This investigation was supported by a research grant from the National Institutes of Health, United States Public Health Service.
Hypoferremia was noted in association with the nephrotic syndrome in one patient by Laurell (7) and was observed by us in two of three children with this condition (5). Laurell found an extremely low serum iron-binding capacity in his patient. Slater and Kunkel (8), using paper electrophoresis, observed a distinct $\beta$-globulin spot in the urine of patients with nephrosis, sometimes without a visible counterpart in the serum. They suggested that this $\beta$-globulin might be serum ironbinding $\beta_{1}$-globulin.

It is the purpose of this paper to present studies on the plasma copper and iron levels and the excretion of these two elements in the urine of patients with the nephrotic syndrome.

\section{METHODS}

The hematologic methods used in this study have been described elsewhere (9). The methods employed have been described in other communications; for the measurement of red blood cell and plasma copper (10); that for the direct-reacting copper fraction of plasma (11); for plasma iron (12); and for total iron-binding capacity of the plasma (13). Total serum protein, albumin and globulin were determined by the biuret method (14) with the modification of Weichselbaum (15). The electrophoretic analyses were performed as described previously (16).

The protein concentration in the urine was determined spectrophotometrically by a modification of the biuret method of Hiller, Greif, and Beckman (17). Sufficient urine to contain 5 to $20 \mathrm{mg}$. of protein was pipetted into a medium-sized pyrex test tube. An equal volume of Tsuchiya's reagent (18) was added to precipitate the proteins. The tubes were centrifuged at 2000 to 2500 r.p.m. for 10 minutes, after which the supernate was decanted off and the tubes drained by inverting on a paper towel. The pellet of protein was dissolved by mixing with $2 \mathrm{ml}$. of a 4 per cent solution of sodium hydroxide. Three $\mathrm{ml}$. of distilled water were then added, followed by $5 \mathrm{ml}$. of the dilute biuret reagent described by Weichselbaum (15). The mixture was allowed to stand 20 to 30 minutes for color development, after which the optical density of the sample, as well as that of a blank prepared in the same manner but without urine, was read by 
the use of an Evelyn colorimeter with a $565 \mathrm{~m}_{\mu}$ filter. If the urine was highly colored, a urine blank was read with $5 \mathrm{ml}$. of a 0.2 per cent solution of sodium hydroxide added in place of the biuret reagent. The protein concentration was obtained from a curve relating the optical density to protein content as obtained by the use of various dilutions of serum, the Kjeldahl method being the standard of reference (19).

For the determination of urinary copper, $20 \mathrm{ml}$. aliquots of urine were transferred to $100 \mathrm{ml}$. Kjeldahl flasks. To each flask were added $1.5 \mathrm{ml}$. concentrated sulfuric acid and $10 \mathrm{ml}$. of concentrated nitric acid. The mixture was digested until charred. It was then cooled, and one $\mathrm{ml}$. of concentrated perchloric acid and $5 \mathrm{ml}$. of concentrated nitric acid were added to each flask, the digestion being continued until the solution became water-clear. The contents were partially cooled, transferred to $10 \mathrm{ml}$. volumetric flasks and made up to volume with redistilled water. A blank was prepared in a similar manner. To one $\mathrm{ml}$. aliquots were added $1.2 \mathrm{ml}$. of a saturated solution of sodium citrate, $0.2 \mathrm{ml}$. of a one per cent solution of gum arabic and $0.8 \mathrm{ml}$. of concentrated ammonium hydroxide. The density $\left(D_{1}\right)$ of the solution was read in a Beckman spectrophotometer at a wave length of $440 \mathrm{~m} \mu$. Two-tenths ml. of a 0.1 per cent solution of sodium diethyldithiocarbamate was added and the density $\left(D_{2}\right)$ determined. The density $\left(D_{3}\right)$ of the blank was then read. The concentration of copper was calculated from the following formula:

$\mathrm{Cu}$ in $\mu \mathrm{g} . / 100 \mathrm{ml}$. urine $=\mathrm{K}\left[\mathrm{D}_{2}-\left(3.2 / 3.4 \mathrm{D}_{1}+\mathrm{D}_{3}\right)\right]$, where $\mathrm{K}$ is the constant derived from the standard curve prepared from analytical grade metallic copper.

For the determination of urinary iron one $\mathrm{ml}$. of the above described diluted digest was pipetted into asmall test tube and $2 \mathrm{ml}$. of saturated aqueous sodium acetate solution added to make the solution basic (red) to congo red paper. One-tenth $\mathrm{ml}$. of thioglycollic acid and 0.4 $\mathrm{ml}$. of a 0.1 per cent solution of O-phenanthroline were added. A blank was prepared in a similar manner. The mixture was allowed to stand one hour for color development after which time the optical density $\left(D_{2}\right)$ was read in the Beckman spectrophotometer at a wave length of $510 \mathrm{~m} \mu$. The density $\left(D_{8}\right)$ of the blank solution was determined and the concentration of iron was calculated from the following formula:

$$
\mathrm{Fe} \text { in } \mu \mathrm{g} . / 100 \mathrm{ml} \text {. urine }=\mathrm{K}\left(\mathrm{D}_{2}-\mathrm{D}_{3}\right), 2
$$

where $\mathrm{K}$ is the constant derived from a standard curve prepared from pure iron wire.

Dialysis of urine copper and iron was carried out in cellophane tubing which had been previously washed with dilute acid and thoroughly rinsed with distilled water. This was done for 18 hours at $2^{\circ} \mathrm{C}$., with occasional agitation. The dialysate was changed twice during the 18 hours. After completion of dialysis the volume of the

2 The $D_{1}$ reading (urine blank) was negligible at 510 $\mathrm{m} \mu$ and, therefore, has been omitted from the formula. sample in the tubing was measured and the copper and iron content of the dialyzed urine were determined as well as that of the urine prior to dialysis.

All of the patients with the nephrotic syndrome studied manifested the classical features of this condition-namely, intractable edema, massive proteinuria, lipemia, and hypoalbuminemia (Table II). The nephrosis in the adults presumably was secondary to chronic glomerulonephritis although in not all of the patients was such a history suggestive of that disease obtainable. In none was the nephrosis associated with intercapillary glomerulo-sclerosis, amyloidosis, syphilis, renal vein thrombosis, or other known rare causes of this syndrome. In all of the children studied the syndrome could be classified as the socalled "pure" or "lipoid nephrosis."

One of the adult patients (E. C.) was somewhat unusual and difficult to classify since, in addition to most of the features of the nephrotic syndrome, there was a moderately severe anemia, elevated blood urea nitrogen, failure to concentrate the urine and other evidence of impaired renal function, and a urinary tract infection. In certain of the other patients complications were present, as indicated in Table II.

Six of the patients (C. E., R. K., G. H., W. B., D. G., and $E$. C.) were studied on a metabolic ward for at least several weeks. The recorded values represent the means of many determinations. In the case of the children, on the other hand, a single blood specimen was studied. ${ }^{3}$

Creatinine values were determined on all specimens of urine.

\section{RESULTS}

Plasma copper, plasma iron, plasma protein, and total iron-binding capacity of the plasma in normal human subjects

Plasma copper values in a total of 218 normal individuals have been determined in this laboratory and have been reported previously $(4,20,21)$. The values for 10 additional male subjects are given in Table I. The mean value ( \pm S.D.) for the entire group of 228 adult subjects is $116 \pm 14$ $\mu \mathrm{g}$. per $100 \mathrm{ml}$. In only 10 subjects (4.4 per cent) has a value of less than $90 \mu \mathrm{g}$. per $100 \mathrm{ml}$. been obtained. In two of the ten, the values were less than $80 \mu \mathrm{g}$. per $100 \mathrm{ml}$., both being 68 . Unpublished observations of Dr. Phillip Sturgeon, who has used our method, showed the mean values in 17 children, 3 to 10 years of age, to be $131 \pm 27$ $\mu \mathrm{g}$. per $100 \mathrm{ml}$. (range 99 to 188 ).

Plasma iron values in a total of 169 normal in-. dividuals have been reported previously from this

${ }^{8} \mathrm{We}$ are indebted to Dr. Phillip Sturgeon, Children's Hospital Society, Los Angeles, Cal., for sending us the case histories and specimens from seven of the children. 
TABLE I

Proteinuria, cupriuria, and siderinuria in ten normal male subjects

\begin{tabular}{|c|c|c|c|c|c|c|c|c|}
\hline \multirow[b]{2}{*}{ Subject } & \multicolumn{5}{|c|}{ Plasma } & \multicolumn{3}{|c|}{ Urine } \\
\hline & Copper & Iron & $\begin{array}{c}\text { Total } \\
\text { protein }\end{array}$ & Albumin & Globulin & Copper & Iron & Protein \\
\hline $\begin{array}{r}1 \\
2 \\
3 \\
4 \\
5 \\
6 \\
7 \\
8 \\
9 \\
10\end{array}$ & $\begin{array}{c}\text { Mg./100 ml. } \\
104 \\
101 \\
113 \\
107 \\
137 \\
113 \\
104 \\
92 \\
96 \\
99\end{array}$ & $\begin{array}{c}\text { Mg. } / 100 \mathrm{ml} \text {. } \\
95 \\
86 \\
119 \\
83 \\
118 \\
192 \\
171 \\
69 \\
100 \\
135\end{array}$ & $\begin{array}{c}\mathrm{Gm} . / 100 \mathrm{ml} . \\
6.2 \\
7.0 \\
6.8 \\
6.5 \\
6.6 \\
6.4 \\
6.6 \\
6.5 \\
7.2 \\
6.1\end{array}$ & $\begin{array}{c}\mathrm{Gm} . / 100 \mathrm{ml} . \\
3.9 \\
4.1 \\
4.1 \\
3.8 \\
4.0 \\
4.3 \\
4.2 \\
4.0 \\
4.3 \\
4.1\end{array}$ & $\begin{array}{c}\mathrm{Gm} . / 100 \mathrm{ml} . \\
2.3 \\
2.9 \\
2.7 \\
2.7 \\
2.6 \\
2.1 \\
2.4 \\
2.5 \\
2.9 \\
2.0\end{array}$ & $\begin{array}{c}\text { Mg./24 hr. } \\
0 \\
0 \\
11 \\
10 \\
8 \\
0 \\
12 \\
26 \\
15 \\
11\end{array}$ & $\begin{array}{c}\text { Mg. } / 24 \mathrm{hr} . \\
40 \\
36 \\
54 \\
32 \\
54 \\
62 \\
57 \\
43 \\
39 \\
64\end{array}$ & $\begin{array}{c}\text { Gm. } / 24 \mathrm{hr} . \\
0.04 \\
0.05 \\
0.07 \\
0.08 \\
0.04 \\
0.03 \\
0.02 \\
0.04 \\
0.02 \\
0.06\end{array}$ \\
\hline Mean & 107 & 117 & 6.6 & 4.1 & 2.5 & 9 & 48 & 0.05 \\
\hline
\end{tabular}

laboratory $(4,13,21,22)$. The values for 10 additional normal subjects are presented in Table I. The mean value ( \pm S.D.) for the entire group of 179 individuals is $110 \pm 31 \mu \mathrm{g}$. per $100 \mathrm{ml}$. Values of less than $70 \mu \mathrm{g}$. per $100 \mathrm{ml}$. have been observed in 15 subjects ( 8 per cent). In four females and one male, values between 39 and $50 \mu \mathrm{g}$. have been obtained. In 17 children, 3 to 10 years of age, Dr. Phillip Sturgeon has found the mean serum iron to be $86 \pm 33 \mu \mathrm{g}$. per $100 \mathrm{ml}$. (range 27 to 153 ) (Unpublished observations).
Plasma total protein, albumin, and globulin values for 10 normal male subjects are recorded in Table I. The mean values were $6.6,4.1$, and 2.5 Gm. per $100 \mathrm{ml}$., respectively.

The total iron-binding capacity of the serum as measured in this laboratory in 30 normal adults was $359 \pm 30.8 \mu \mathrm{g}$. per $100 \mathrm{ml}$. (13). Dr. Phillip Sturgeon's value for 13 children 3 to 10 years of age is $404 \pm 118 \mu \mathrm{g}$. per $100 \mathrm{ml}$. No significant difference between the total iron-binding capacity of the serum and of the plasma has been observed.

TABLE II

Nephrotic syndrome

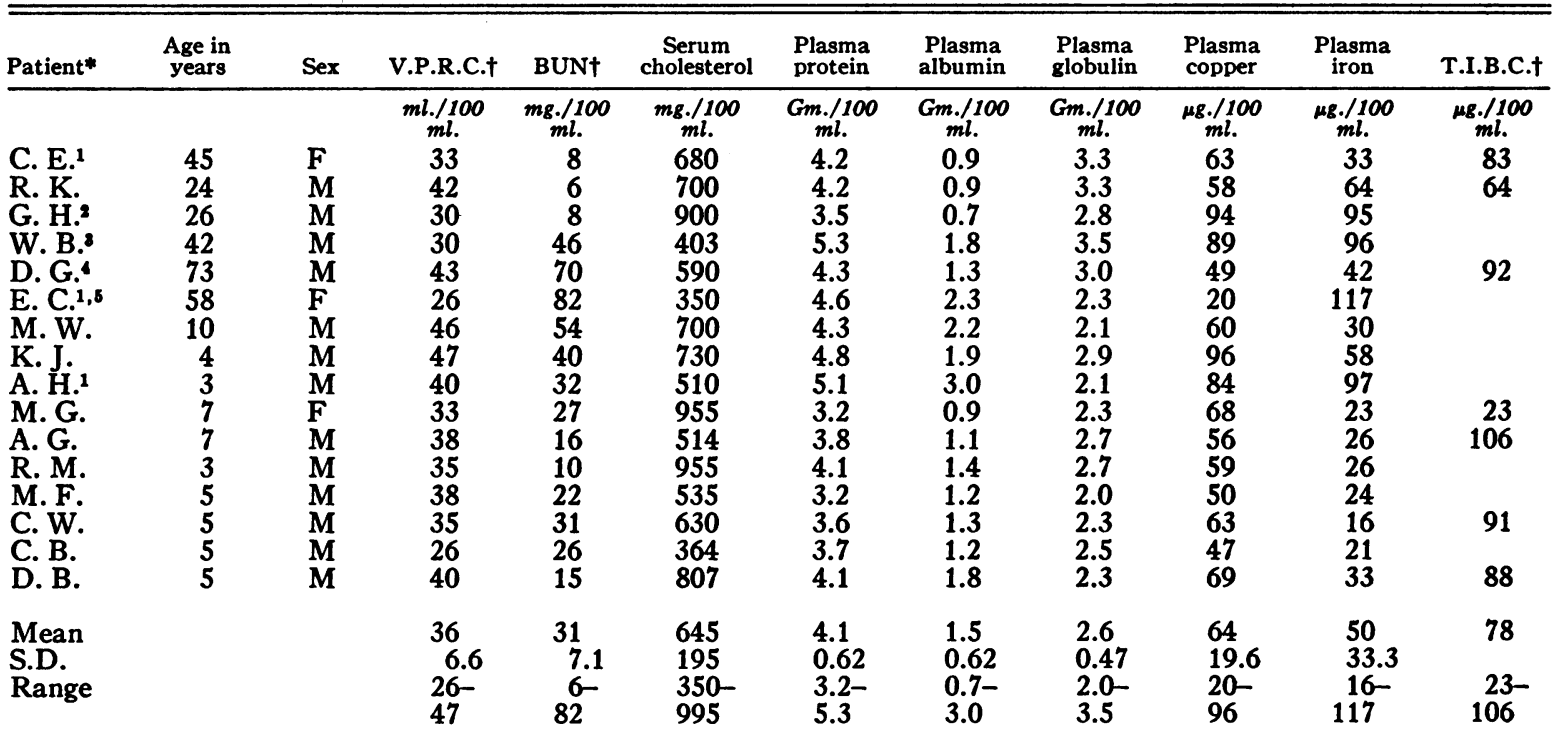

${ }^{*} 1$ Associated urinary tract infection; ${ }^{2}$ associated bronchiectasis; ${ }^{8}$ pneumonia; ${ }^{4}$ gout; ${ }^{8}$ uremia complicating the nephrotic syndrome. plasma.

†.P.R.C., volume of packed red cells; BUN, blood urea nitrogen; T.I.B.C., total iron binding capacity of the 


\section{Urinary copper, iron and protein in normal human} subjects

The values for urinary copper, iron and protein in 10 normal male adults are given in Table I together with the plasma values of copper, iron, and protein in these individuals.

The mean excretion of copper per 24 hours was $9 \mu$ g., with a range from 0 to 26 . The mean excretion of iron per 24 hours was $48 \mu \mathrm{g}$., with a range from 32 to $64 \mu \mathrm{g}$. The excretion of protein was negligible, with a mean value of $0.05 \mathrm{Gm}$. per 24 hours and a range of 0.02 to 0.08 .

Plasma copper, plasma iron and the total ironbinding capacity of the plasma in the nephrotic syndrome.

The values for plasma copper and iron for sixteen patients with the nephrotic syndrome are presented in Table II. The mean value ( \pm S. D.) for the group was $64 \pm 20 \mu \mathrm{g}$. per $100 \mathrm{ml}$. The value observed for plasma copper was more than two standard deviations below the normal mean in 13 of the 16 patients. In 10 of the 16 patients the plasma copper levels were lower than the lowest value observed in a normal subject.

The mean value ( \pm S.D.) for the plasma iron

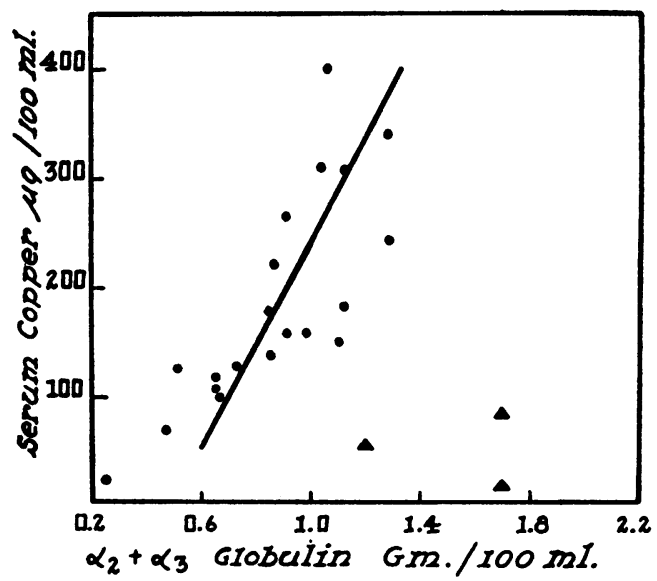

Fig. 1. The Corpelation between the Plasma Copper Level and the $\alpha_{2}+\alpha_{3}$ Globulin Fraction of Seruac in Normal Human Subjects and Subjects with Hypercupremia (Pregnancy, Infections aNd Leuremia) (Dors)

In the three patients (C. E., D. G., and E. C.) with the nephrotic syndrome ( $\Delta$ ) the serum copper levels were low but the globulin level was high. The diagonal line was plotted by the method of least squares.

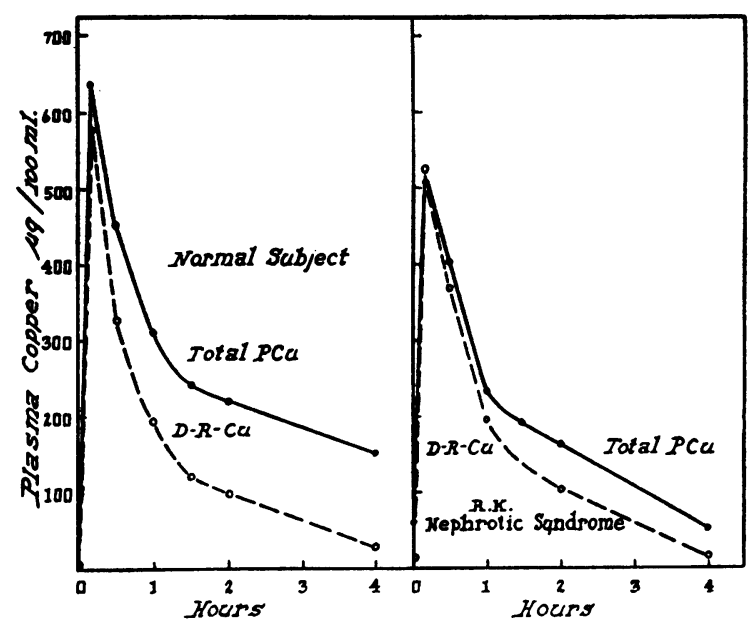

Fig. 2. The Removal of Copper from the Plasma Following the Intravenous Administration of 100 Mg. of "Cupralene" to a Normal Subject and to a Patient WITH THE NEPHROTIC SYNDROME

The rate of removal of copper during the first 1.5 hours was the same in each individual. In both the normal subject and the patient most of the copper injected was in the direct-reacting (D-R-Cu) fraction.

level for the entire group was $50 \pm 33 \mu \mathrm{g}$. per 100 $\mathrm{ml}$. The mean value in the adults was $74 \mu \mathrm{g}$. per $100 \mathrm{ml}$. and in the children it was $35 \mu \mathrm{g}$. per $100 \mathrm{ml}$.

Due to the lipemic nature of the plasma, the total iron-binding capacity could be determined reliably in only seven of the patients. In all of these there was a marked reduction but the mean per cent saturation of the protein with iron was 53 per cent ( 26 to 100 ) as compared with a mean of 35 per cent (26 to 49) for normal subjects (13).

Red blood cell copper determinations were performed in five patients. In two of these (C. E. and W. B.) the values were normal, 94 and $87 \mu \mathrm{g}$. per $100 \mathrm{ml}$. of packed $\mathrm{RBC}$, respectively. In two (R. K. and D. G.) the values of 61 and $71 \mu \mathrm{g}$. per $100 \mathrm{ml}$. were more than two standard deviations below the normal male mean of $110 \mu \mathrm{g}$. per $100 \mathrm{ml}$. (21). In the fifth patient (E. C.) the extremely low value of $40 \mu \mathrm{g}$. was obtained. It may be significant that this patient had the lowest plasma copper level of all of the patients studied.

In a previous communication (16) it was noted that in normal subjects and in patients with hypercupremia (pregnancy, infections, leukemia) the serum copper level correlates closely (correlation coefficient of +0.79 ) with the $\alpha_{2}+\alpha_{3}$ globulin fraction of the serum proteins as determined by 
TABLE III

Proteinuria, cupriuria, and siderinuria in patients with the nephrotic syndrome*

\begin{tabular}{|c|c|c|c|c|c|c|c|c|}
\hline \multirow[b]{3}{*}{ Patient } & \multirow{2}{*}{\multicolumn{2}{|c|}{ Plasma }} & \multicolumn{6}{|c|}{ Urine } \\
\hline & & & \multirow{2}{*}{$\begin{array}{c}\text { No. of } \\
\text { determi- } \\
\text { nations }\end{array}$} & \multirow[b]{2}{*}{ Protein } & \multirow[b]{2}{*}{ Copper } & \multirow{2}{*}{$\frac{C_{u}}{P}$} & \multirow[b]{2}{*}{ Iron } & \multirow{2}{*}{$\frac{F e}{P}$} \\
\hline & Copper & Iron & & & & & & \\
\hline $\begin{array}{l}\text { C. E. } \\
\text { R. K. } \\
\text { G. H. } \\
\text { W. B. } \\
\text { D. G. } \\
\text { E. C. }\end{array}$ & $\begin{array}{c}\text { Ag. } / 100 \mathrm{ml} . \\
63 \\
58 \\
94 \\
89 \\
49 \\
20\end{array}$ & $\begin{array}{c}\text { Mg. } / 100 \mathrm{ml} . \\
33 \\
64 \\
95 \\
96 \\
42 \\
117\end{array}$ & $\begin{array}{r}10 \\
12 \\
11 \\
11 \\
6 \\
3\end{array}$ & $\begin{array}{c}\text { Gm. } / 24 \text { hr. } \\
8.8 \\
15.4 \\
12.2 \\
5.6 \\
18.4 \\
9.3\end{array}$ & $\begin{array}{c}\mu \mathrm{g} . / 24 \mathrm{hr} . \\
270 \\
490 \\
346 \\
183 \\
324 \\
92\end{array}$ & $\begin{array}{l}31 \\
32 \\
28 \\
33 \\
18 \\
10\end{array}$ & $\begin{array}{c}\mu \mathrm{g} . / 24 \mathrm{kr} . \\
466 \\
864 \\
610 \\
453 \\
480\end{array}$ & $\begin{array}{l}53 \\
56 \\
50 \\
\\
25 \\
52\end{array}$ \\
\hline
\end{tabular}

* The ratios are expressed in $\mu \mathrm{g}$. of copper $(\mathrm{Cu})$ or iron $(\mathrm{Fe})$ per gram of protein $(\mathrm{P})$.

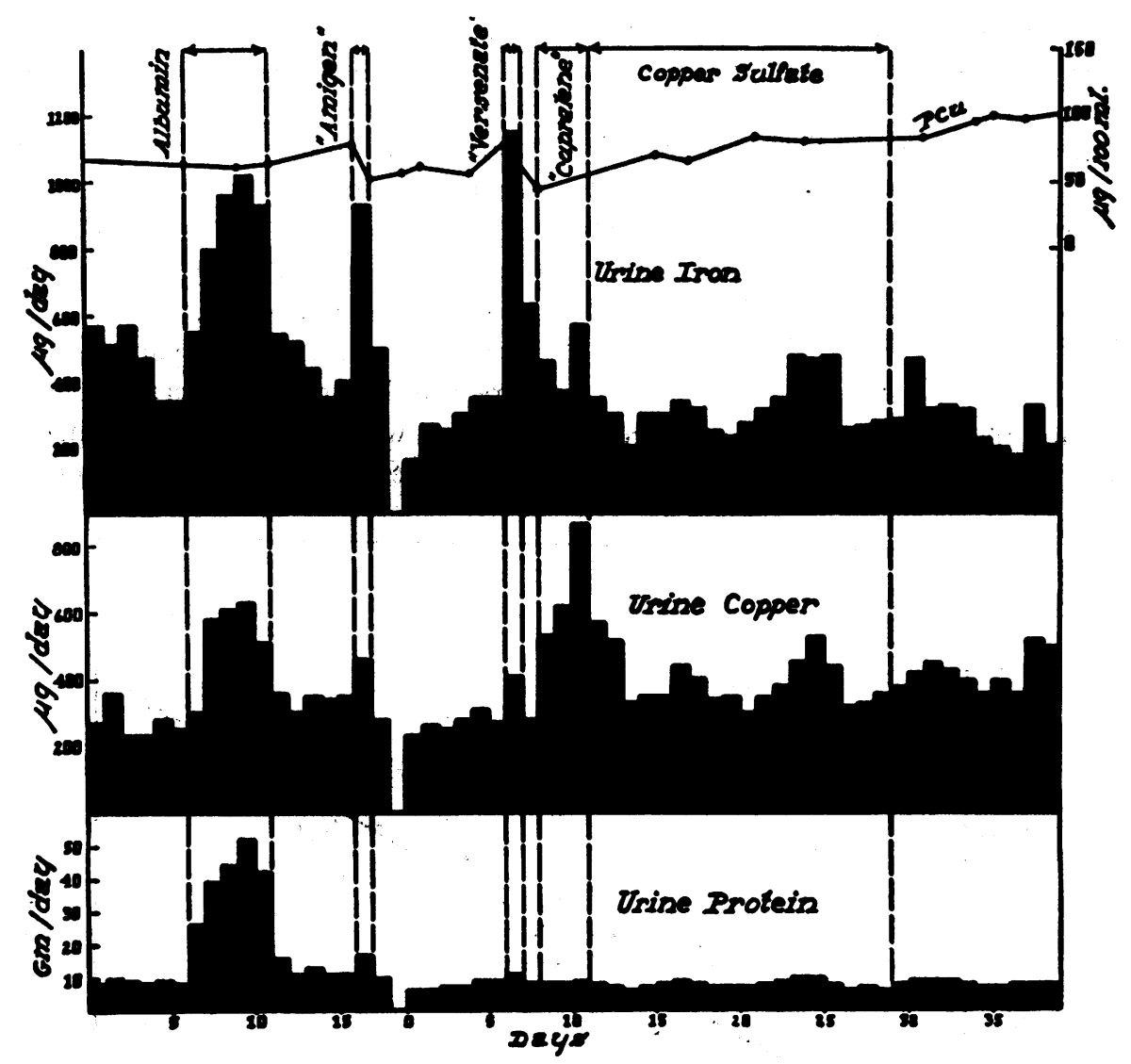

Fig. 3. The Influence of the Administration of Albumin, "Amigen," "Calcium Versenate," “Cupralene," and Copper Sulfate on the Urinary Excretion of Protein, Copper, and Iron and on the Plasma Copper level in a Patient (C. E.) with THE NEPHROTIC SYNDROME

Fifty grams of human serum albumin were given daily for five days. One liter of casein hydrolysate ("Amigen") was next given intravenously. This was followed by a single intravenous injecton of one gram of the calcium disodium salt of ethylenediamine tetraacetic acid ("Versenate"). For three consecutive days, $100 \mathrm{mg}$. of allylcuprothiocarbamate ("Cupralene") was given intravenously each day. Finally copper sulfate was administered by mouth in an amount of $33 \mathrm{mg}$. three times a day for a period of 18 days. 
electrophoretic analysis. Since it is known that the serum of patients with the nephrotic syndrome contains increased amounts of $\alpha_{2}+\alpha_{3}$ globulins (23), it is of interest that in this condition no such correlation was observed (Figure 1).

In an effort to study the disappearance rate of intravenously administered copper, $100 \mathrm{mg}$. of "Cupralene" (allylcuprothiocarbamide, containing 19.93 per cent copper) were administered to a patient with the nephrotic syndrome and the results compared with the disappearance rate in a normal subject (Figure 2). In the nephrotic patient the starting value was lower but the magnitude of increase was comparable to the increase in the normal subject and the rate of disappearance from the plasma was the same in both individuals. In both the normal subject and the patient with the nephrotic syndrome, within the limits of experimental error all of the injected copper appeared in the direct-reacting fraction of the plasma copper (11).

\section{Urinary copper, iron and protein in the nephrotic syndrome}

Mean values for the encretion of copper, iron, and protein in the urine of six petients are pre- sented in Table III. The plasma values for copper and iron are also given.

The patients excreted from 92 to $490 \mu \mathrm{g}$. of copper per day. In the first four patients (C. E., R. K., G. H., and W. B.) the copper/protein ratio was extremely constant. Approximately 31 $\mu \mathrm{g}$. of copper were excreted per gram of protein. Prior to the administration of various substances this ratio was relatively constant from day to day in each of the six adult patients. This is illustrated in a single patient (C. E.) in Figure 3. The ratio was significantly lower (18 and 10$)$ in patients D. G. and E. C. It is of interest that the plasma copper levels in these two patients were extremely low.

In Figure 4, the daily urinary protein values are plotted against the daily values for the excretion of copper in the first four patients of Table III. The mean value for ten normal subjects (Table $I$ ) is also plotted. The correlation coefficient $(r)$ for these values is +0.97 . Only the mean values for the determinations on E. C. and D. G., have been platted. In both of these patients, as noted above, there was less copper excreted per gram of protin than was excreted in the other four patients. The excretion of iron was somewhat greater

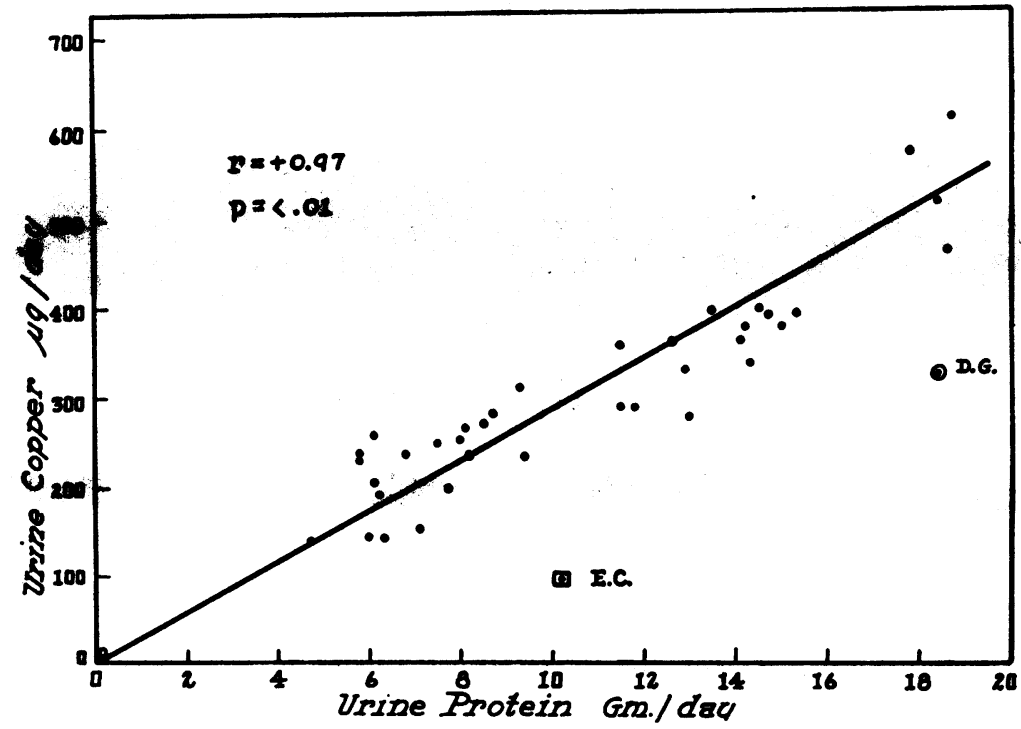

Fig. 4. The Correxation between the Datly Urinary Excretion of Copper and Protein in Four Patients (C. E., R. K., G. H., and W. B.) WITH THE NEPHROTIC SYNDROME

The mean value for 10 normal subjects (open dot, lower left hand corner) and the mean values for patients D. G. and E. C. are alșo given. The line was plotted by the method of least squares. 


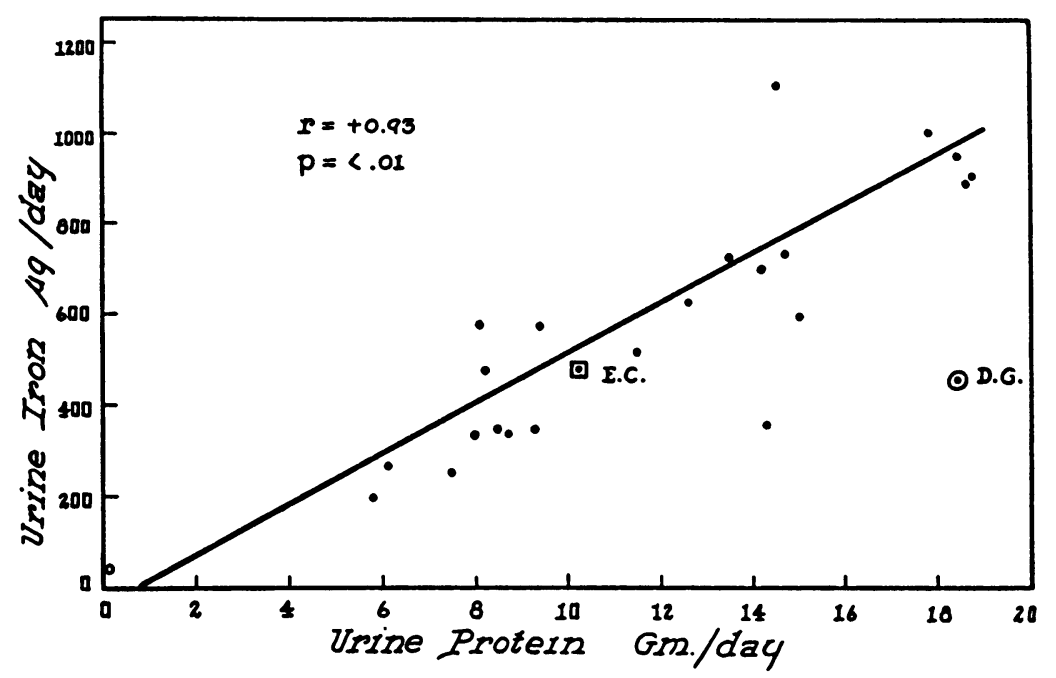

Fig. 5. The Correlation between the Daily Urinary Excretion of Iron and Protein in Three Patients (C. E., R. K., and G. H.) with the NePHROTIC SYNDROME

The mean values for 10 normal subjects (open dot) and the mean values for D. G. and E. C. are also given. The line was plotted by the method of least squares.

than that of copper and ranged from 453 to 864 $\mu \mathrm{g}$. per day. The ratio iron/protein varied from 50 to 60 in four of the patients but was only 25 in one of the patients (D. G.). In this patient the plasma iron was low. However, it should be noted that in patient C. E. the plasma iron was equally low and yet the urinary iron/protein ratio was 53 . The iron/protein ratio was relatively constant from day to day in patient C.E., as illustrated in Figure 3.

In Figure 5, the daily urinary protein excretion is plotted against the daily iron excretion for three of the patients (C. E., R. K., and G. H.). The mean value for the 10 normal subjects (Table I) is also shown. The correlation coefficient $(r)$ for these data is +0.93 . Only the mean values for E. C. and D. G. have been plotted. The mean value for E. C. fell on the line. In the case of D. G., as noted above, the mean value fell below the line.

Specimens of urine from all six of the patients were dialyzed repeatedly against distilled water for 18 hours at $2^{\circ} \mathrm{C}$. In no instance was a detectable quantity of the copper or iron dialyzable.

In order to study the influence of various substances on the urinary copper/protein and iron/ protein ratios, human serum albumin, casein hydrolysate ("Amigen"), allylcuprothiocarbamide ("Cupralene"), and the calcium disodium salt of ethylenediamine tetra-acetic acid ("Calcium Versenate") were given intravenously, and copper

TABLE IV

Proteinuria, cupriuria, and siderinuria during the intravenous administration of albumin*

\begin{tabular}{|c|c|c|c|c|c|c|}
\hline Patient & Period & Protein & Copper & $\frac{\mathrm{Cu}}{\mathrm{P}}$ & Iron & $\frac{\mathrm{Fe}}{\mathrm{P}}$ \\
\hline C. E. & $\begin{array}{l}\text { Before } \\
\text { During }\end{array}$ & $\begin{array}{c}G m . / 24 \text { hrs. } \\
8.8 \\
52.2\end{array}$ & $\begin{array}{c}g . / 24 \text { hrs. } \\
270 \\
625\end{array}$ & $\begin{array}{l}31 \\
12\end{array}$ & $\begin{array}{c}\mu g . / 24 \text { hrs. } \\
466 \\
1020\end{array}$ & $\begin{array}{l}53 \\
19\end{array}$ \\
\hline G. H. & $\begin{array}{l}\text { Before } \\
\text { During }\end{array}$ & $\begin{array}{l}12.2 \\
38.6\end{array}$ & $\begin{array}{l}346 \\
464\end{array}$ & $\begin{array}{l}28 \\
12\end{array}$ & $\begin{array}{r}610 \\
1060\end{array}$ & $\begin{array}{l}50 \\
27\end{array}$ \\
\hline G. H. & $\begin{array}{l}\text { Before } \\
\text { During }\end{array}$ & $\begin{array}{r}8.4 \\
21.5\end{array}$ & $\begin{array}{l}225 \\
351\end{array}$ & $\begin{array}{l}27 \\
16\end{array}$ & $\begin{array}{l}391 \\
643\end{array}$ & $\begin{array}{l}47 \\
30\end{array}$ \\
\hline
\end{tabular}

* The ratios are expressed in $\mu$ g. of copper $(\mathrm{Cu})$ or iron $(\mathrm{Fe})$ per gram of protein $(\mathrm{P})$. 
TABLE V

Proteinuria, cupriuria, and siderinuria during the intravenous administration of casein hydrolysate*

\begin{tabular}{|c|c|c|c|c|c|c|}
\hline Patient & Period & Protein & Copper & $\frac{\mathbf{C u}}{\mathbf{P}}$ & Iron & $\frac{\mathrm{Fe}}{\mathrm{P}}$ \\
\hline C. E. & $\begin{array}{l}\text { Before } \\
\text { During }\end{array}$ & $\begin{array}{c}\text { Gm./24 hrs. } \\
11.6 \\
16.6\end{array}$ & 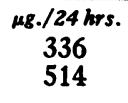 & $\begin{array}{l}29 \\
31\end{array}$ & $\begin{array}{c}\text { Mg./24 hrs. } \\
426 \\
934\end{array}$ & $\begin{array}{l}38 \\
56\end{array}$ \\
\hline R. K. & $\begin{array}{l}\text { Before } \\
\text { During }\end{array}$ & $\begin{array}{l}17.1 \\
16.3\end{array}$ & $\begin{array}{l}489 \\
569\end{array}$ & $\begin{array}{l}29 \\
35\end{array}$ & $\begin{array}{r}863 \\
1184\end{array}$ & $\begin{array}{l}50 \\
73\end{array}$ \\
\hline D. G. & $\begin{array}{l}\text { Before } \\
\text { During }\end{array}$ & $\begin{array}{l}19.8 \\
20.3\end{array}$ & $\begin{array}{l}314 \\
419\end{array}$ & $\begin{array}{l}16 \\
21\end{array}$ & $\begin{array}{r}444 \\
1000\end{array}$ & $\begin{array}{l}22 \\
49\end{array}$ \\
\hline
\end{tabular}

* The ratios are expressed in $\mu \mathrm{g}$. of copper $(\mathrm{Cu})$ or iron $(\mathrm{Fe})$ per gram of protein $(\mathrm{P})$.

sulfate was given orally to each of several patients.

The relationship of intravenously administered human serum albumin to the urinary copper/protein and iron/protein ratios is summarized in Table IV. C. E. was given 50 grams of albumin daily for four days. G. H. on two separate occasions received 25 grams daily for two consecutive days. In each case, the administration of albumin was associated with a significant increase in the excretion of both copper and iron. However, the increase in urinary total protein was considerably greater, with the result that there was a significant decrease in the copper/protein and iron/protein ratios.

The intravenous administration of one liter of casein hydrolysate (Table V) in each case was associated with a modest but significant increase in the excretion of copper and a somewhat greater diuresis of iron. However, in two of the patients there was a slight increase in the excretion of protein with the result that the copper/protein and iron/protein ratios increased only slightly.

The intravenous injection of "Cupralene" resulted in a moderate to marked increase in the copper/protein ratio but there was no significant increase in the iron/protein ratio in the two patients in whom the latter was studied (Table VI). In spite of the increase in the copper/protein ratio, only a small amount ( 0.4 to 2.4 per cent) of the copper injected appeared in the urine during the brief period of study. Patients W. B. and R. K. were given a single intravenous injection of 100 mg. of the compound. Patient C. E. was given $100 \mathrm{mg}$. daily for three consecutive days.

The influence of the oral administration of copper sulfate on the urinary copper/protein and iron/ protein ratios in three patients is summarized in Table VII. Patients W. B. and R. K. were given $33 \mathrm{mg}$. of copper sulfate $\left(5 \mathrm{H}_{2} \mathrm{O}\right)$ three times a day with meals for five days. Patient C. E. was given the same daily amount of copper for a period of 18 days. In each of the three patients there was a distinct increase in the copper/protein ratio. The iron/protein ratio was not altered significantly.

A single intravenous injection of one gram of "Calcium Versenate" (Table VIII) resulted in no appreciable increase in the excretion of copper in

TABLE VI

Proteinuria, cupriuria, and siderinuria during the intravenous administration of "Cupralene" *

\begin{tabular}{|c|c|c|c|c|c|c|c|}
\hline Patient & Period & Protein & Copper & $\frac{C u}{P}$ & $\begin{array}{l}\text { Per cent } \\
\text { copper } \\
\text { excreted }\end{array}$ & Iron & $\frac{\mathrm{Fe}}{\mathrm{P}}$ \\
\hline W. B. & $\begin{array}{l}\text { Before } \\
\text { During }\end{array}$ & $\begin{array}{c}\text { Gm. } / 24 \text { hrs. } \\
5.8 \\
5.8\end{array}$ & $\begin{array}{c}\text { Me./24 hrs. } \\
106 \\
190\end{array}$ & $\begin{array}{l}18 \\
32\end{array}$ & 0.4 & Ms. 124 hrs. & \\
\hline C. E. & $\begin{array}{l}\text { Before } \\
\text { During }\end{array}$ & $\begin{array}{l}7.1 \\
8.3\end{array}$ & $\begin{array}{l}252 \\
746\end{array}$ & $\begin{array}{l}36 \\
90\end{array}$ & 2.4 & $\begin{array}{l}345 \\
469\end{array}$ & $\begin{array}{l}49 \\
55\end{array}$ \\
\hline R. K. & $\begin{array}{l}\text { Before } \\
\text { During }\end{array}$ & $\begin{array}{l}13.4 \\
13.4\end{array}$ & $\begin{array}{l}403 \\
573\end{array}$ & $\begin{array}{l}30 \\
43\end{array}$ & 0.9 & $\begin{array}{l}798 \\
794\end{array}$ & $\begin{array}{l}60 \\
59\end{array}$ \\
\hline
\end{tabular}

* The ratios are expressed in $\mu \mathrm{g}$. of copper $(\mathrm{Cu})$ or iron $(\mathrm{Fe})$ per gram of protein $(\mathrm{P})$. 
TABLE VII

Proteinuria, cupriuria, and siderinuria during the oral administration of copper sulfate*

\begin{tabular}{|c|c|c|c|c|c|c|}
\hline Patient & Period & Protein & Copper & $\frac{\mathrm{Cu}}{\mathrm{P}}$ & Iron & $\frac{\mathrm{Fe}}{\mathrm{P}}$ \\
\hline W. B. & $\begin{array}{l}\text { Before } \\
\text { During }\end{array}$ & $\begin{array}{c}\text { Gm. } / 24 \text { hrs. } \\
6.1 \\
3.9\end{array}$ & $\begin{array}{c}\mu g . / 24 \text { hrs. } \\
114 \\
131\end{array}$ & $\begin{array}{l}19 \\
35\end{array}$ & Mg./24 hrs. & \\
\hline R. K. & $\begin{array}{l}\text { Before } \\
\text { During }\end{array}$ & $\begin{array}{l}15.8 \\
13.2\end{array}$ & $\begin{array}{l}411 \\
508\end{array}$ & $\begin{array}{l}26 \\
38\end{array}$ & $\begin{array}{l}864 \\
744\end{array}$ & $\begin{array}{l}51 \\
56\end{array}$ \\
\hline C. E. & $\begin{array}{l}\text { Before } \\
\text { During }\end{array}$ & $\begin{array}{l}7.4 \\
6.9\end{array}$ & $\begin{array}{l}264 \\
330\end{array}$ & $\begin{array}{l}36 \\
48\end{array}$ & $\begin{array}{l}273 \\
266\end{array}$ & $\begin{array}{l}37 \\
38\end{array}$ \\
\hline
\end{tabular}

* The ratios are expressed in $\mu \mathrm{g}$. of copper $(\mathrm{Cu})$ or iron $(\mathrm{Fe})$ per gram of protein $(\mathrm{P})$.

relation to protein but was associated with a striking increase in the excretion of iron.

The influence of albumin, casein hydrolysate, "Calcium Versenate," "Cupralene," and copper sulfate on the excretion of copper, iron, and protein in the urine of one of the patients (C.E.) is illustrated graphically in Figure 3.

\section{Hematologic studies in the nephrotic syndrome}

As shown in Table II, a mild degree of anemia (volume of packed red cells between 30 and $33 \mathrm{ml}$. per $100 \mathrm{ml}$.) was present in three of the six adult patients. In a fourth patient (E. C.) a moderately severe anemia existed. However, the condition was somewhat complicated in this patient in that uremia was also present. Anemia of a mild degree was present in five of the ten children and in one the anemia was moderately severe.

The morphologic characteristics of the erythrocytes as well as the percentage of reticulocytes and the leukocyte and platelet counts in the six adult patients are presented in Table IX. In all instances the erythrocytes were normal in size and hemoglobin content. Anemia, when present, was unaccompanied by reticulocytosis or a sig- nificant alteration in the leukocyte or platelet level.

The changes associated with the administration of copper by mouth are summarized in Table $\mathrm{X}$. Two of the patients (W. B. and R. K.) were given $33 \mathrm{mg}$. of copper sulfate $\left(5 \mathrm{H}_{2} \mathrm{O}\right)$ three times daily with meals for a period of five days. The third patient was given this amount of copper for a period of 18 days. In none of the patients was this therapy followed by a significant reticulocytosis or a significant increase in the volume of packed red cells. In one of the patients (W. B.), at the time this therapy was instituted the plasma copper level was normal. In a second patient (R. K.), the level of copper in the plasma was reduced but did not rise with therapy. In the patient given the longest course of therapy (C. E.), the administration of copper was associated with an increase in the plasma copper level to within the normal range. It should be noted that in this patient the oral therapy was immediately preceded by the intravenous administration of "Cupralene" for three days (Figure 4). In neither of the two patients in whom the plasma iron level was studied, was there any increase in this value following the administration of copper.

TABLE VIII

Proteinuria, cupriuria, and siderinuria during the intravenous administration of "Calcium Versenate" *

\begin{tabular}{|c|c|c|c|c|c|c|}
\hline Patient & Period & Protein & Copper & $\frac{\mathrm{Cu}}{\mathrm{P}}$ & Iron & $\frac{\mathrm{Fe}}{\mathrm{P}}$ \\
\hline C. E. & $\begin{array}{l}\text { Before } \\
\text { During }\end{array}$ & $\begin{array}{c}\text { Gm. } / 24 \text { hrs. } \\
7.4 \\
10.9\end{array}$ & $\begin{array}{c}\text { Mg. } / 24 \text { hrs. } \\
264 \\
410\end{array}$ & $\begin{array}{l}36 \\
38\end{array}$ & $\begin{array}{c}\text { Mg. } / 24 \text { hrs. } \\
273 \\
1150\end{array}$ & $\begin{array}{r}37 \\
105\end{array}$ \\
\hline R. K. & $\begin{array}{l}\text { Before } \\
\text { During }\end{array}$ & $\begin{array}{l}15.9 \\
16.1\end{array}$ & $\begin{array}{l}710 \\
744\end{array}$ & $\begin{array}{l}45 \\
46\end{array}$ & $\begin{array}{r}786 \\
1755\end{array}$ & $\begin{array}{r}50 \\
109\end{array}$ \\
\hline
\end{tabular}

* The ratios are expressed in $\mu \mathrm{g}$. of copper $(\mathrm{Cu})$ or iron $(\mathrm{Fe})$ per gram of protein $(\mathrm{P})$. 
TABLE IX

Hematologic data in the patients with the nephrotic syndrome*

\begin{tabular}{|c|c|c|c|c|c|c|}
\hline Patient & V.P.R.C. & M.C.V. & M.C.H.C. & Retics. & W.B.C. & Platelets \\
\hline $\begin{array}{l}\text { C. E. } \\
\text { R. K. } \\
\text { G. H. } \\
\text { W. B. } \\
\text { D. G. } \\
\text { E. C. }\end{array}$ & $\begin{array}{c}m l . / 100 \mathrm{ml} . \\
33 \\
42 \\
30 \\
30 \\
43 \\
26\end{array}$ & $\begin{array}{l}C \mu \\
82 \\
88 \\
80 \\
88 \\
89 \\
88\end{array}$ & $\begin{array}{l}\% \\
35 \\
32 \\
35 \\
35 \\
34 \\
35\end{array}$ & $\begin{array}{c}\% \\
1.8 \\
0.8 \\
0.5 \\
1.4 \\
1.0 \\
1.4\end{array}$ & $\begin{array}{c}\times 10^{3} / \mathrm{mm} .^{2} \\
5.2 \\
8.7 \\
3.6 \\
10.2 \\
6.2 \\
5.5\end{array}$ & $\begin{array}{c}\times 10^{3} / \mathrm{mm} . \\
184 \\
280 \\
300 \\
320 \\
230 \\
240\end{array}$ \\
\hline
\end{tabular}

*V.P.R.C., volume of packed red cells; M.C.V., mean corpuscular volume; M.C.H.C., mean corpuscular hemoglobin concentration; Retics., reticulocytes; W.B.C., white blood cell count.

\section{Plasma copper and iron in patients with uremia}

To ascertain if hypocupremia and hypoferremia occur in patients with severe impairment of renal function but without massive proteinuria, the plasma copper and iron levels were studied in seven patients with uremia (Table XI). In none of the patients was hypocupremia observed. In two of the patients hypercupremia was present. A reduction of the plasma iron level was observed in three of the patients. These observations are in accordance with previous studies in this laboratory (4).

\section{Plasma copper and plasma iron in hypoalbumi-} nemic states other than the nephrotic syndrome

To determine if hypocupremia and hypoferremia occur in hypoalbuminemic states other than the nephrotic syndrome, studies were made in five patients with cirrhosis of the liver, a patient with nutritional hypoalbuminemia, and a single patient with sprue (Table XII). In none was hypocupremia present and a significant reduction in the plasma iron level was observed in only one patient.

TABLE $\mathbf{X}$

The influence of the oral administration of copper sulfate on the blood

\begin{tabular}{|c|c|c|c|c|c|}
\hline Patient & Day & V.P.R.C.* & $\begin{array}{l}\text { Retic. } \\
\text { Peak }\end{array}$ & $\begin{array}{l}\text { Plasma } \\
\text { copper }\end{array}$ & $\begin{array}{c}\text { Plasma } \\
\text { iron }\end{array}$ \\
\hline C. E. & $\begin{array}{r}0 \\
18\end{array}$ & $\begin{array}{c}\mathrm{ml.} / 100 \mathrm{ml} . \\
34 \\
33\end{array}$ & $\begin{array}{c}\% \\
1.8 \\
3.1\end{array}$ & $\begin{array}{c}\text { mg./100 ml. } \\
57 \\
101\end{array}$ & $\begin{array}{c}\mu g . / 100 \mathrm{ml} \\
35 \\
30\end{array}$ \\
\hline W. B. & $\begin{array}{l}\mathbf{0} \\
\mathbf{5}\end{array}$ & $\begin{array}{l}31 \\
31\end{array}$ & $\begin{array}{l}2.3 \\
2.0\end{array}$ & $\begin{array}{l}115 \\
106\end{array}$ & \\
\hline R. K. & $\begin{array}{l}0 \\
5\end{array}$ & $\begin{array}{l}43 \\
44\end{array}$ & $\begin{array}{l}1.6 \\
1.6\end{array}$ & $\begin{array}{l}60 \\
48\end{array}$ & $\begin{array}{l}66 \\
59\end{array}$ \\
\hline
\end{tabular}

* V.P.R.C., volume of packed red cells.

\section{DISCUSSION}

From the data presented it is evident that, in at least some patients with the nephrotic syndrome, there is a markedly increased excretion of copper and iron in the urine with a concomitant reduction in the plasma level of these two elements. It seems likely that the hypocupremia and the hypoferremia are, in part at least, the consequence of the loss of ceruloplasmin and transferrin into the urine. For the present, however, this is but an assumption, since ceruloplasmin and transferrin were not isolated and identified in the urine. Nevertheless, it is not unreasonable to think that these two relatively low molecular weight proteins will pass through the kidney in nephrosis.

Several observations indirectly support this view. First, the decrease in the plasma concentration of copper and iron appeared to be associated with a decrease in the concentration of both ceruloplasmin and transferrin. Thus, since approximately 96 per cent of all of the copper in plasma is normally present as ceruloplasmin $(1,11)$, in all of the patients with a marked reduction in the plasma copper level, it is probable that there was a reduction in the ceruloplasmin concentration. That the concentration of the transferrin was reduced is indicated by the recorded values for total-iron binding capacity of the plasma. Secondly, the observations that neither element could be dialyzed from the urine and that there was a high degree of correlation between the amount of proteinuria and the amount of iron and copper in the urine, indicate that these elements were bound to protein. That such binding to protein was not indiscriminate, however, was indicated by the observation that, when albumin was administered intravenously there was a marked reduction in the ratio of copper 
TABLE XI

Plasma copper and iron in patients with uremia

\begin{tabular}{|c|c|c|c|c|c|c|c|}
\hline Patient & V.P.R.C.* & BUN* & $\begin{array}{c}\text { Total } \\
\text { plasma } \\
\text { protein }\end{array}$ & $\begin{array}{l}\text { Plasma } \\
\text { albumin }\end{array}$ & $\begin{array}{c}\text { Plasma } \\
\text { globulin }\end{array}$ & $\begin{array}{l}\text { Plasma } \\
\text { copper }\end{array}$ & $\underset{\text { iron }}{\text { Plasma }}$ \\
\hline $\begin{array}{l}\text { D. T. } \\
\text { V. L. } \\
\text { D. H. } \\
\text { L. F. } \\
\text { V. J. } \\
\text { F. L. } \\
\text { M. L. }\end{array}$ & $\begin{array}{c}\mathrm{ml} . / 100 \mathrm{ml} . \\
26 \\
23 \\
24 \\
26 \\
25 \\
36 \\
32\end{array}$ & $\begin{array}{c}\mathrm{mg} . / 100 \mathrm{ml} . \\
114 \\
190 \\
129 \\
80 \\
204 \\
129 \\
148\end{array}$ & $\begin{array}{c}G m . / 100 \mathrm{ml} . \\
6.2 \\
6.2 \\
5.6 \\
4.8 \\
6.6 \\
7.2 \\
4.5\end{array}$ & $\begin{array}{c}\mathrm{Gm} . / 100 \mathrm{ml} . \\
3.6 \\
5.0 \\
3.9 \\
2.7 \\
2.9 \\
4.0 \\
2.5\end{array}$ & $\begin{array}{c}\mathrm{Gm} . / 100 \mathrm{ml} . \\
2.6 \\
1.2 \\
1.7 \\
2.1 \\
3.7 \\
3.2 \\
2.0\end{array}$ & $\begin{array}{c}\text { mg./100 ml. } \\
101 \\
119 \\
181 \\
149 \\
161 \\
134 \\
104\end{array}$ & $\begin{array}{c}\text { Mg./100 ml. } \\
82 \\
162 \\
63 \\
94 \\
59 \\
102 \\
36\end{array}$ \\
\hline
\end{tabular}

* V.P.R.C., volume of packed red cells; BUN, blood urea nitrogen.

and iron to protein in the urine. This would suggest that copper and iron were not being excreted bound to albumin. The observed increase in the absolute amount of excreted copper and iron could be explained by a greater loss of ceruloplasmin and transferrin secondary to the increased glomerular filtration rate which is known to occur following the intravenous administration of albumin (24). Finally, if copper and iron were to be excreted other than as ceruloplasmin and transferrin, a renal mechanism for the removal of copper and iron from these proteins and for combining them with other proteins would have to be postulated. Obviously, there is no such mechanism present in the normal kidney since, at most, only negligible amounts of these elements are excreted in the urine. It seems unlikely that such a mechanism would be present in the kidneys of patients with the nephrotic syndrome.

However, if the hypocupremia and hypoferremia are to be explained solely on the basis of the loss of ceruloplasmin and transferrin in the urine, it then follows that the degree of reduction of these two proteins in the plasma, assuming the initial stores to be equal and the rate of synthesis to be constant, should depend upon the duration of the nephrotic state and the amounts of these two proteins lost in the urine. In this study, in a small group of patients observed for a comparatively short period of time there was no apparent correlation between the duration of the syndrome and the plasma copper and iron levels. Likewise, there was no correlation in six patients between the degree of cupriuria or siderinuria and the degree of hypocupremia or hypoferremia. In two of the patients (G. H. and W. B.) with plasma copper values within the normal range, and in two of the patients (G. H. and E. C.) with normal plasma iron values, there was a marked degree of cupriuria and siderinuria. Admittedly, if a larger group of patients were to be studied through the entire course of their illness, such a correlation might be found. At this point it can only be stated that the limited data available suggest that the levels of copper and iron in the plasma depend upon other factors in addition to the degree of urinary loss.

Hypercupremia is known to be present in patients with infections (25). In the patients with the nephrotic syndrome with recognized infections there was a tendency for the hypocupremia to be

TABLE XII

Plasma copper and iron in hypoalbuminemic states other than the nephrotic syndrome

\begin{tabular}{|c|c|c|c|c|c|c|}
\hline Patients & Diagnosis & $\begin{array}{c}\text { Total } \\
\text { plasma } \\
\text { protein }\end{array}$ & $\begin{array}{c}\text { Plasma } \\
\text { albumin }\end{array}$ & $\begin{array}{l}\text { Plasma } \\
\text { globulin }\end{array}$ & $\begin{array}{l}\text { Plasma } \\
\text { copper }\end{array}$ & $\begin{array}{c}\text { Plasma } \\
\text { iron }\end{array}$ \\
\hline $\begin{array}{l}\text { R. V. } \\
\text { R. Q. } \\
\text { R. P. } \\
\text { A. M. } \\
\text { B. H. } \\
\text { L. L. }\end{array}$ & $\begin{array}{l}\text { Cirrhosis of liver } \\
\text { Cirrhosis of liver } \\
\text { Cirrhosis of liver } \\
\text { Cirrhosis of liver } \\
\text { Cirrhosis of liver } \\
\text { Nutritional hypo- } \\
\text { albuminemia }\end{array}$ & $\begin{array}{c}\mathrm{Gm} . / 100 \mathrm{ml} . \\
7.0 \\
5.8 \\
6.7 \\
5.9 \\
5.5 \\
6.0\end{array}$ & $\begin{array}{c}\text { Gm./100 ml. } \\
2.6 \\
2.5 \\
2.3 \\
2.0 \\
2.1 \\
2.1\end{array}$ & $\begin{array}{c}G m . / 100 \mathrm{ml} . \\
4.4 \\
3.3 \\
4.4 \\
3.9 \\
3.4 \\
3.9\end{array}$ & $\begin{array}{c}\mu g . / 100 \mathrm{ml} . \\
156 \\
133 \\
101 \\
159 \\
132 \\
155\end{array}$ & $\begin{array}{c}\mu g . / 100 \mathrm{ml} . \\
126 \\
116 \\
135 \\
87 \\
110 \\
56\end{array}$ \\
\hline M. M. & Sprue & 4.8 & 2.9 & 1.9 & 113 & 22 \\
\hline
\end{tabular}


less severe than in those without infections but this correlation did not hold in all of the cases and a severe degree of hypocupremia was present in several patients with complicating infections. It is possible that in several of the patients infection contributed to the reduction in the plasma iron level, but a recognized complicating infection of mild nature was present in the four patients with a normal plasma iron level and in the other patients hypoferremia existed in the absence of a recognized infection.

In addition to the above, the fact that hypocupremia and hypoferremia are not present in all patients with the nephrotic state, even when there is considerable loss of copper and iron in the urine, suggests the possibility that in such patients there may be considerable variation in the ability of the body to synthesize these two metal-containing proteins. Severe hypocupremia and hypoferremia may develop only when urinary loss is accompanied by an impaired rate of synthesis.

In the two patients (D. G. and E. C.) with the lowest plasma copper levels, the ratio of copper to protein in the urine was considerably lower than in the other four with higher plasma copper values. It may be that when the plasma copper level falls below a certain value, the rate of loss in the urine diminishes.

The intravenous administration of casein hydrolysate was associated with a definite increase in the amount of copper and iron in the urine. In all three instances this increase was greater than the increase in proteinuria. This suggests that a small amount of copper and iron may have been excreted as a complex with aminoacids. However, none of the copper or iron was dialyzable from the urine.

We have no information concerning the degree of depletion of copper and iron in the body of patients with the nephrotic syndrome. It would be desirable, if the occasion should present itself, to measure the copper and iron content of the tissues, particularly the liver and spleen. The finding of a low content of copper in the erythrocytes of three of the five patients in whom this determination was performed suggests that in at least certain of the tissues of some patients there may be a significant depletion of copper. In the copperdeficient swine $(26,27)$ it has been found that the concentration of copper in the erythrocytes does not decline until the deficiency becomes severe.

Since severe iron deficiency in human subjects is manifested by a microcytic, hypochromic anemia, and copper-deficiency in swine is accompanied by a similar type of anemia (26), it would seem unlikely that depletion of these two elements is the explanation for the normocytic, normochromic type of anemia which accompanies the nephrotic state in human subjects. This is also suggested by the observations reported here, limited though they were, in which the anemia failed to respond to the administration of copper.

In a recent comprehensive study (5) of the plasma copper level in approximately 200 patients with a variety of diseases, it was pointed out that hypocupremia is an extremely uncommon finding. To date, hypocupremia has been observed consistently in human subjects in only three situations; namely, the newborn (28), Wilson's disease (5, $29,30)$, and the nephrotic syndrome. A dietary deficiency of copper has not, as yet, been clearly demonstrated in a human subject (31).

\section{SUM MARY}

Hypocupremia was observed in 13 of 16 patients with the nephrotic syndrome and hypoferremia in 10 of the 16. The mean plasma copper level in the 16 patients was $64 \pm 20 \mu \mathrm{g}$. per $100 \mathrm{ml}$. as compared with $116 \pm 14 \mu \mathrm{g}$. per $100 \mathrm{ml}$. in normal subjects. The mean plasma iron value was $50 \pm$ $33 \mu \mathrm{g}$. per $100 \mathrm{ml}$. as compared with the normal mean of $110 \pm 31 \mu \mathrm{g}$. per $100 \mathrm{ml}$. The total ironbinding capacity of the plasma, determined in seven patients, was found to be reduced in all seven. The mean value was $78 \mu \mathrm{g}$. per $100 \mathrm{ml}$. as compared with the normal mean of 359 .

Patients with the nephrotic syndrome were found to excrete increased quantities of copper and iron in the urine. The copper and iron were not dialyzable and the amount excreted was correlated with the amount of protein present in the urine. Approximately $31 \mu \mathrm{g}$. of copper and $53 \mu \mathrm{g}$. of iron were excreted per gram of protein. However, following the intravenous administration of albumin there was a marked increase in the degree of proteinuria and but only a slight increase in the amount of copper and iron excreted.

Hypocupremia was not observed in patients 
with uremia or hypoalbuminemic states other than the nephrotic syndrome. Hypoferremia was observed in a few patients with these conditions.

It is suggested that the hypocupremia and the hypoferremia associated with the nephrotic state are, in part at least, the consequence of the loss of ceruloplasmin and transferrin in the urine. However, the possibility that there is impairment in the rate of synthesis of these two metal-binding proteins in some patients cannot be ruled out.

Red blood cell copper was found to be reduced in three of five patients in whom this determination was made. The anemia failed to respond to the administration of copper in a limited number of patients in whom this was studied.

\section{ACKNOWLEDGMENTS}

We are indebted to Dr. Harold Brown, Chief of the Medical Service, Veterans Administration Hospital, for his advice and cooperation and to Dr. Frank Tyler for the creatinine determinations. Dr. Emil Smith and Mr. Douglas Brown kindly performed the electrophoretic analyses. The "Cupralene" was supplied by Dr. J. M. Carlisle, Merck and Company, Rahway, New Jersey. Dr. N. W. Karr, Riker Laboratories, Inc., Los Angeles, California, furnished the intravenous solutions of "Calcium Versenate." The casein hydrolysate ("Amigen") was generously supplied by Dr. W. M. Cox, Jr., Mead Johnson and Co., Evansville, Indiana.

\section{REFERENCES}

1. Holmberg, C. G., and Laurell, C.-B., Investigations in serum copper. I. Nature of serum copper and its relation to the iron-binding protein in human serum. Acta chem. Scandinav., 1947, 1, 944.

2. Holmberg, C. G., and Laurell, C.-B., Investigations in serum copper. II. Isolation of the copper containing protein, and a description of some of its properties. Acta chem. Scandinav., 1948, 2, 550.

3. Surgenor, D. M., Koechlin, B. A., and Strong, L. E., Chemical, clinical, and immunological studies on the products of human plasma fractionation. XXXVII. The metal-combining globulin of human plasma. J. Clin. Invest., 1949, 28, 73.

4. Cartwright, G. E., Huguley, C. M., Jr., Ashenbrucker, H., Fay, J., and Wintrobe, M. M., Studies on free erythrocyte protoporphyrin, plasma iron and plasma copper in normal and anemic subjects. Blood, 1948, 3, 501.

5. Lahey, M. E., Gubler, C. J., Cartwright, G. E., and Wintrobe, M. M., Studies on copper metabolism. VII. Blood copper in pregnancy and various pathological states. J. Clin. Invest., 1953, 32, 329.
6. Munch-Petersen, S., On the copper content in urine in proteinemia. Scandinav. J. Clin. \& Lab. Invest., 1950, 2, 337.

7. Laurell, C.-B., Studies on the transportation and metabolism of iron in the body with special reference to the iron-binding component in human plasma. Acta physiol. Scandinav., 1947, 14, Suppl. 46.

8. Slater, R. J., and Kunkel, H. G., Filter paper electrophoresis with special reference to urinary proteins. J. Lab. \& Clin. Med., 1953, 41, 619.

9. Wintrobe, M. M., Clinical Hematology, ed. 3., Philadelphia, Lea and Febiger, 1951.

10. Gubler, C. J., Lahey, M. E., Ashenbrucker, H., Cartwright, G. E., and Wintrobe, M. M., Studies on copper metabolism. I. A method for the determination of copper in whole blood, red blood cells, and plasma. J. Biol. Chem., 1952, 196, 209.

11. Gubler, C. J., Lahey, M. E., Cartwright, G. E., and Wintrobe, M. M., Studies on copper metabolism. IX. The transportation of copper in blood. J. Clin. Invest., 1953, 32, 405.

12. Hamilton, L. D., Gubler, C. J., Cartwright, G. E., and Wintrobe, M. M., Diurnal variation in the plasma iron level of man. Proc. Soc. Exper. Biol. \& Med., 1950, 75, 65.

13. Cartwright, G. E., and Wintrobe, M. M., Chemical, clinical and immunological studies on the products of human plasma fractionation. XXXIX. The anemia of infection. Studies on the iron-binding capacity of serum. J. Clin. Invest., 1949, 28, 86.

14. Kingsley, G. R., The determination of serum total protein, albumin, and globulin by the biuret reaction. J. Biol. Chem., 1939, 131, 197.

15. Weichselbaum, T. E., An accurate and rapid method for the determination of proteins in small amounts of blood serum and plasma. Am. J. Clin. Path. Technical section, 1946, 10, 40.

16. Lahey, M. E., Gubler, C. J., Brown, D. M., Smith, E. L., Jager, B. V., Cartwright, G. E., and Wintrobe, M .M., Studies on copper metabolism. VIII. The correlation between the serum copper level and various serum protein fractions. J. Lab. \& Clin. Med., 1953, 41, 829.

17. Hiller, A., Greif, R. L., and Beckman, W. W., Determination of protein in the urine by the biuret method. J. Biol. Chem., 1948, 176, 1421.

18. Addis, T., Barrett, E., Boyd, R. I., and Ureen, H. J., Renin proteinuria in the rat. I. The relation between proteinuria and the pressor effect of renin. J. Exper. Med., 1949, 89, 131.

19. Heyrovský, A., and Sochorová, I., Quantitative determination of urinary protein. Acta med. Scandinav., 1951, 141, 65.

20. Cartwright, G. E., Jones, P. J., and Wintrobe, M. M., A method for the determination of copper in blood serum. J. Biol. Chem., 1945, 160, 593.

21. Lahey, M. E., Gubler, C. J., Cartwright, G. E., and Wintrobe, M. M., Studies on copper metabolism. 
VI. Blood copper in normal human subjects. J. Clin. Invest., 1953, 32, 322.

22. Cartwright, G. E., Lauritsen, M. A., Jones, P. J., Merrill, I. M., and Wintrobe, M. M., The anemia of infection. I. Hypoferremia, hypercupremia, and alterations in porphyrin metabolism in patients. J. Clin. Invest., 1946, 25, 65.

23. Luetscher, J. A., Jr., Electrophoretic analysis of plasma and urinary proteins. J. Clin. Invest., 1940, $19,313$.

24. Luetscher, J. A., Jr., Hall, A. D., and Kremer, V. L., Treatment of nephrosis with concentrated human serum albumin. II. Effects on renal function and on excretion of water and some electrolytes. J. Clin. Invest., 1950, 29, 896.

25. Cartwright, G. E., and Wintrobe, M. M., The anemia of infection. XVII. A review, Advances in Internal Medicine, Vol. V, I. Snapper and W. Dock, eds., Chicago, The Year Book Publishers, Inc., 1952, pp. 165-226.

26. Lahey, M. E., Gubler, C. J., Chase, M. S., Cartwright, G. E., and Wintrobe, M. M., Studies on copper metabolism. II. Hematologic manifestations of copper deficiency in swine. Blood, 1952, 7, 1053.

27. Gubler, C. J., Lahey, M. E., Chase, M. S., Cartwright, G. E., and Wintrobe, M. M., Studies on copper metabolism. III. The metabolism of iron in copper deficient swine. Blood, 1952, 7, 1075.

28. Fay, J., Cartwright, G. E., and Wintrobe, M. M., Studies on free erythrocyte protoporphyrin, serum iron, serum iron-binding capacity and plasma copper during normal pregnancy. J. Clin. Invest., 1949, 28, 487.

29. Bearn, A. G., and Kunkel, H. G., Biochemical abnormalities in Wilson's disease. J. Clin. Invest., 1952, 31,616 .

30. Scheinberg, I. H., and Gitlen, D., Deficiency of ceruloplasmin in patients with hepatolenticular degeneration (Wilson's disease). Science, 1952, 116, 484.

31. Cartwright, G. E., Copper metabolism in human subjects in Copper Metabolism: A Symposium on Animal, Plant, and Soil Relationships, W. D. McElroy and B. Glass, eds., Baltimore, John Hopkins University Press, 1950, pp. 274-312. 